\title{
\begin{tabular}{ll}
\hline 臨 & 床 \\
\hline
\end{tabular} \\ 高音急墜型突発性難聴の臨床的特徴
}

岡本 牧人・設楽 哲也

\section{Glinical Features of Sudden Deafness in Patients with Impaired Hearing of High Tones}

\author{
Makito Okamoto and Tetsuya Shitara \\ (Kitasato University)
}

Although there are several types of sudden idiopathic sensori-neural hearing loss, this study focused on patients who had impaired mainly hearing of high tones due to sensori-neural hearing loss of the following types:

1. suddenly onset cured within a few days,

2. in those with lesions limited to the basal turn of the cochlea,

3. sudden idiopathic inner ear lesion of the semicircular canal, vestibule and basal turn of the cochlea,

4. increasing over a few days,

5. due to obstruction of the vestibulo-cochlear artery,

6. due to a perilymph fistula.

The following practical clinical factors should be considered:

At the onset was there barotrauma, drug intoxication or sound injury? From the onset to the first examination was the patient subjectively aware of a change in his level of hearing? To determinate the cause, supraliminal hearing tests, obserbations of positional and positioning nystagmus and caloric tests should be performed in the early stage of the disease. Anti-coagulant therapy was administered to one patient suspected of having arterial obstruction, and probe tympanotomy was needed by the patient who was suspected of having a perilymph fistula.

\section{はじめに}

突発性難聴調査研究班による突発性難德の全国的調査が行われてから10年が経過した。当時は突 発性難聴の全体像を捉えるために，よ゙ちらかというと広義の突発性難恥を集める必要があった。し かし最近，てうして集められた症候群としての突発性難蚛を分類するてとが試みられるようになっ た. 分類の基準としては原因別あるいは病理学的相違によることが望ましいが，哭発性難聴自体が 原因不明の智患であるので，分類法としては，臨休的態度あるいは検査所見によることにならざる 
をえない，我々は，高音のみが障害された急性感音難聴について検沽し，焱発性難衶診断基準上高 音障害型急性感音難聴は突発性難聴に含められると述べたが'1, 各症例を検討した結果, 臨床上い くつかの興味ある点が見出されたので報告する.

\section{対}

象

対象は，1971年 7 月より1982年12月までに北 里大学病院耳鼻呐喉科難㯖外来に登録された, 発症日の明らかな, 笑然に発症した原因不明の 感音難聴 527 例のうち, 初搒時から固定将まで の標準純音缌力検査において，一度でも急墜型 を示した64例である。

急墜型の始まる䦌波数は $1 \mathrm{KHz}$ 以上とし た。また，反対倒に感音難聰を有するものは， その聴力型の如何を問わず今回の対象から除外 した.

64例を発症から初診までの日数で分けると， $0 \sim 3$ 日，22例， $4 \sim 7$ 日, 18例， $8 \sim 30$ 日， 15例, 31 日以上, 9 例であった（表 1 ）.

結

\begin{tabular}{|c|c|c|c|c|}
\hline $\begin{array}{l}\text { 初㟝まで } \\
\text { の日数 }\end{array}$ & $\begin{array}{l}\text { 初揨時 } \\
\text { 急隊型 }\end{array}$ & 初 診 時 & $\begin{array}{l}\text { 初喨後 } \\
\text { 悪化型 }\end{array}$ & 計 \\
\hline $0-3$ 日 & 13 & 6 & 3 & 22 \\
\hline $4-7$ 日 & 7 & 9 & 2 & 18 \\
\hline $8-30$ 日 & 11 & 3 & 1 & 15 \\
\hline 31日一 & 9 & 0 & 0 & 9 \\
\hline 計 & 40 & 18 & 6 & 64 \\
\hline
\end{tabular}

\section{1. 純音恥力について}

発症 7 日以内に受診し, 初診㑐急塗型を示す type は20例であった。このうち，5例は，発 症から受診までに，目営的に恥》改善を認めた あのであった。

初診時急隤型以外の症例で, 経過川, 急隊型 をとる屯のは，18例であった。乙の18例の初診 時聴力型は, 水平型 9 例, 高音漸倾型 9 例であ った。乙れらが，急墜型となる時期は平均值で 23日，中央值で13日であった。また，てのうち 3 例は発症 7 日以内に急隊型となった。

一力，乲発性難恥の特殊型として，数日かけ て難溭が悪化していく type の難揌がある. 我 々の経験した 9 例のうち， 6 例が経過中急墜型 をとった（図1）。乙の6 例はい-゙れれ初診时 急豲型で, 経過の羊かった症例 6 を除き 5 日か ら11日で悪化し，15日から27日で固定した。覀 化時の聴力型は水平型 4 例, 高音漸倾型 1 例, また，固定時の聴力型は，急墜型 4 例，高音漸

倾型 1 例であった。四 1 の症例 8 の急㧭型は $0.25 \mathrm{~K}$ と0. $5 \mathrm{KHz}$ との聞が隊ちていたために， 今回の急陶型の対象には入れなかった例であ る.

2. 域值上聴力検査について

64例川，48例にベケシーの自記オージオメト リーを行ったＩ型17例 $(35.4 \%) ，$ II 型21 例 $(43.8 \%) ，$ III 型 7 例 $(14.6 \%)$ であった (表 2 )。また, S I S I テストは45例山137例 （82.2\%）に陽性であった。しかし, 発症 7 日 以内受診例の初診侍急隊型に限ると, III型 3 例 (21.4\%), S I S I 陽性 8 例 $(57.1 \%)$ であ った。

3.めまいについて

めまいを伴う頻度は，64例ゆ139例（60.9\%）

で通常の突発性難聴よりやや多かった，発症 7 日以内に受診し, 発症から受診までに恥力改善 を自覚した 5 例ではめまいはみられなかった。 これに対し，同期間に受㡣し，受㟝までに聰力 


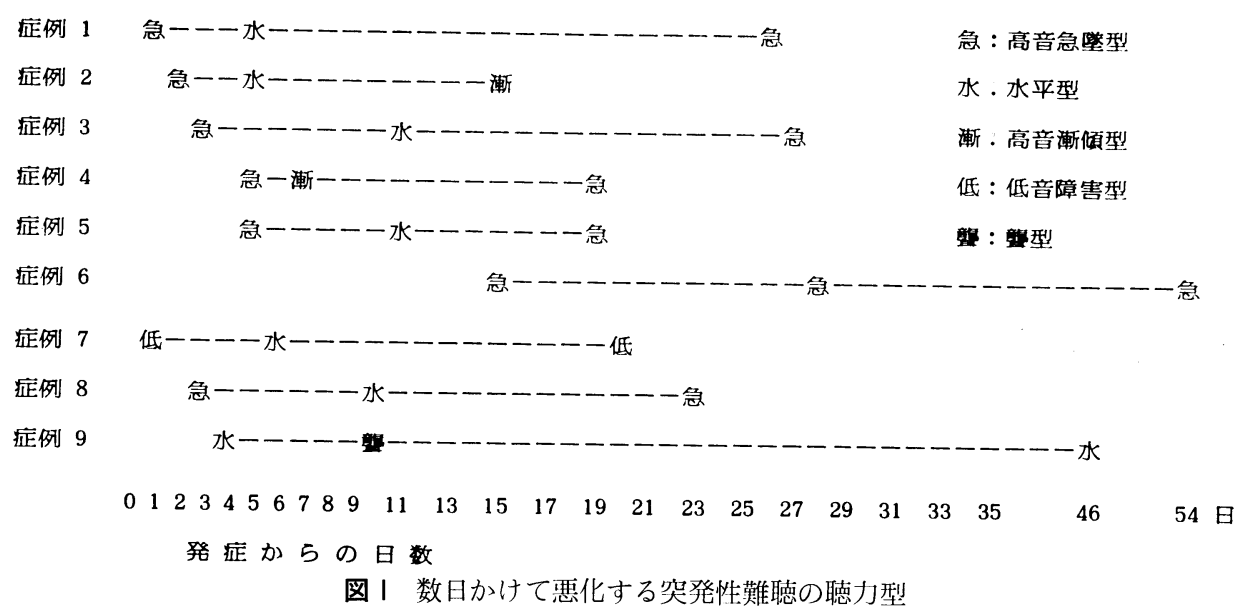

表 2 自記オージオメトリーの結果

\begin{tabular}{|c|c|c|c|}
\hline Jerger 分類 & 対象症例 & \begin{tabular}{|} 
初揨時急墜型 \\
(7 日以内受 \\
誩例)
\end{tabular} & $\begin{array}{l}\text { 急栵型以 } \\
\text { 桀発 } \\
\text { 性難聴 }\end{array}$ \\
\hline I 型 & 17 & 8 & 38 \\
\hline II 型 & 21 & 3 & 45 \\
\hline III 型 & 7 & 3 & 3 \\
\hline IV 型 & 0 & 0 & 1 \\
\hline 検査できず & 3 & 0 & 0 \\
\hline 計 & 48 & 14 & 87 \\
\hline
\end{tabular}

改善を自覚しなかった15例では，10例66.7\%に めまいがみられた。

一方， B P P N様眼振を呈したものが 6 例み られた。この 6 例のうち, カロリックテストを 施行されたのは 4 例で, C P 2 例, 健側 D P 1 例，正常 1 例であった。 6 例の初診時聴力を図 2 亿示す.

\section{4. 成績}

発症 7 日以内受診例の予後をみると, 40 例 中, 治癒11例 $(27.5 \%)$, 著明回復16例 (40.0 $\%)$, 回復 7 例 $(17.5 \%)$, 不変 6 例 $(15.0 \%)$ であった。これは，本院における一般の突発性 難聴の成績と比へ，治癒例が少なく著明回復例 が多い結果であった（表 3 ).

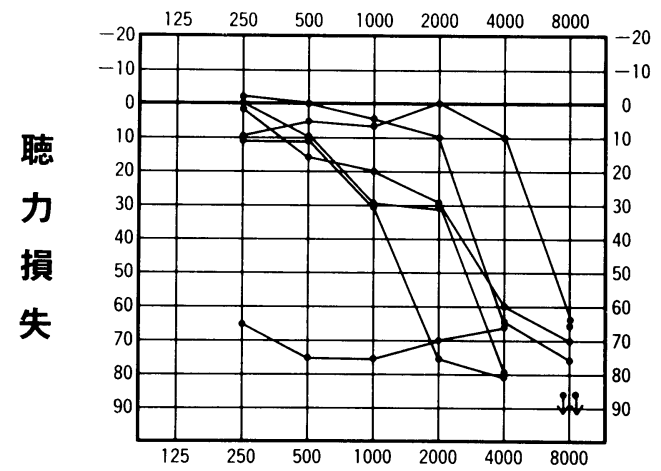

図 2 B P P N样眼振を示した 6 例の初診時オ一 ジオグラム

表 3 発症 7 日以内受㟝例の予後

\begin{tabular}{|c|c|c|c|}
\hline & & $\begin{array}{l}\text { 急墜 型 } \\
\text { 聟性難聴 }\end{array}$ & $\begin{array}{l}\text { 急糗型以外の } \\
\text { 発性難聴 }\end{array}$ \\
\hline 治 & 癒 & 11 & 111 \\
\hline 著 明 回 & 復 & 16 & 58 \\
\hline 回 & 復 & 7 & 45 \\
\hline 不 & 変 & 6 & 31 \\
\hline 尌 & & 40 & 245 \\
\hline
\end{tabular}


考

いわゆる突発性難聴のゆで，主として高音の みが障宫される type のものを突発性難恥とす るべきかどうかは, 結局, 突発性難聴診断の手

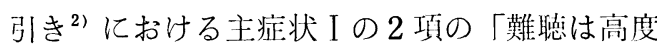
の感音難聴である」と，その説朋(1)の「必ずし 6高度である必要はないが，高度でないと実際 に難聴になったととに気づかないことが多い」 の解釈にゆだねられる。我々は64症例について 検討した結果, 高音のみが障害された type の あのでも定義上突発性難聴之して差し支えない と結論した。しかし，ての64症例がいくつかの 異った集団の集まりであることは，今问の検湖 結果からも明らかであろう。したがって，高音 が障蕶された type の突発性難聴に遭遇した埸 合, 我々は, その特徽をよく把据して, 問診, 検査，治療をすすめる必要があると思われた。 以下，順を迎って考察をすすめていく。

発症早期（7 日以内）から高音急隊型を呈す る type には, 二つのものがある。すなわち， 非常に早く回復する type の突発性難媤で経過 中あるいは固定時に高音急墜型となる type 之 最初から主として高音のみが障贯される type の乫発性難聴である.

一般に, 数口で治癒する type の资発性難聴 は（それを突発性難聴とするべきかどうかとい う議論屯あるが）低音障害型や水平型（通常 $50 \mathrm{dBHL}$ 程度まで）に多い，とてろが，それら が完全に治癒するのに対し，高育念譐型では高 音障害を残してしまう。それが，高音急隊型の 屯のと，低音障害型や水平型のものとが別の病 態であるためなのか, それとも, 同じ病態で, 高音部の易傷性, 非可逆性によるためなのかは 分からない。しかし，7 日以内に回復して高音 急墜型となるものは，めまいを伴う例が $1 / 7$

(14.3\%) と少なく, 内耳障寄は蝸牛に，しか む, 特に高音域に限局していると考えられる。

これに対して, 最初から高音障暃型で発症す る type のものは, めまいを伴う頻度が $10 / 15$
按

（66.7\%）上多いのが特徵で, 突発性内耳障害 という概念からみれば，障部价が前庭，半規 管よりに起こった将態と考えられる。

以上の二つの type は, 早期に受䧐した場合 はオージオグラムによって，また，受診が遅れ た埸合は問診によって，鑑別できる。したがっ て, 発症から受診までの聴力改善の自覚の有無 をよく問診する必要がある，ところで，高音急 墜型の突発性難聴をみた場合，もう一つ注意し なければならないのは，発症から受診までの間 に揌力が覀化していないかということである。

これは, 笑発性難聴の特殊型に, 数日かけて悪 化していく typeのものがあり, しかむ, 我々 の経験では，そのうちの66.7\%が急墜型であっ たためである。このような type の難聴は柳 田 ${ }^{3)}$ が Slow type の突発性難恥, 寺山文 が急 速進行性感音難聴として報告したものとほぼ同 一の屯のと思われる。柳田によれば，その頻度 は11/600（1.8\%）で我々の9/527（1.7\%）と ほぼ一致した。初診時高音障害型のものは柳田 によれば $3 / 11(27.3 \%)$, 寺川の報告では0/9で あるが，平沖5) の症例献售では 2 例と屯高音急 隊型であった。このように，施設により頻度に 养:はみら机るが, 進行する type の突発性難聴 の中に，当初急隊型をとるものがあるとと，ま た逆に, 発症 7 日以内に受彰した初診時急墜 型25例中，その後さらに悪化したものが 5 例 （20.0\%）あったととから, 急隊型の突発性難 聴をみた埸合, その後の聴力悪化に留意する必 要があると思われた。

高音急隊型難聴の域值上聴力検査にあたって は，検查周波数における恥力が正常な埸合があ り，その解釈に悩まされる。

ベケシーの亩オージオメトリーでIII型をと る頻度は14.6\%, 発症 7 口以内受㟝例の初晾時 急譐型に限ると $21.4 \%$ ，一般の突発性難聴之 比べ， $5 \%$ 以下の危険率で有意に而型の頻度が 高かった。 III型をとった 7 例のうち, その後再 
検したものは 2 例で 1 例は【型になったが， 1 例はIII型のままであった。 III型の 7 例には特に 臨床的特徵は見出せなかった。 今後, 急隊型突 発性難聴の症例を積み重ねて, その意義を検㗅 する必要があると思われた。

急墜型突発性難聴のめまいの頻度は, 一般の 突発性難聴における報告（村上 ${ }^{6}$ ： $41.6 \%$, 三 宅 ${ }^{7}: 37.5 \%$ ）と比べて多く，特に早期に治癒 する限局型蝸牛障害の例を除くと $67.9 \%$ にな る。乙れは, 高音急墜型の突発性難聴は障害部 位が蝸牛の基底回転から前庭, 半規管よりにあ るためと思われた。このように, 解剖学的位置 関係から症状が推测できるが, その点, B P P $\mathrm{N}$ 様眼振を伴うものはさらに興味がある ${ }^{8)}$. B P P Vは耳石器の障害により生ずる屯のといわ れる ${ }^{9)}$. これに, 蝸牛の基底回転の障害が加わ
り，カロリックテストにより，(外側）半規管 機能が正常であったとすれば，前庭蝸牛動脈単 独の血行障害が考えられる（図 3 参照）。とう いう病態は早期に捉える必要があり, 初診時め まいを伴う急墜型突発性難聴をみた埸合，頭什。 変换眼振検査抒よびカロリックテストを必ず行 うように心がけねばならない。一方, 癸発性難 聴の治療に血栓溶解剂を使うことがあるが ${ }^{10)}$, こういう症例にてそ積極的に使ってみてはどう かと考えた。

予後については, 発症 7 日以内の初診例を中 心に検讨したが, 高音急墜型乫発性難聴の予後 判定に笑発性難媤の予後判定基準を用いるとと は次のような問題があると思われた。第一に， 初診時聴力（進行型では最㤠時聴力）之固定時 聴力の差である。 $0.25 \mathrm{KHz}$ から $4 \mathrm{KHz}$ までの

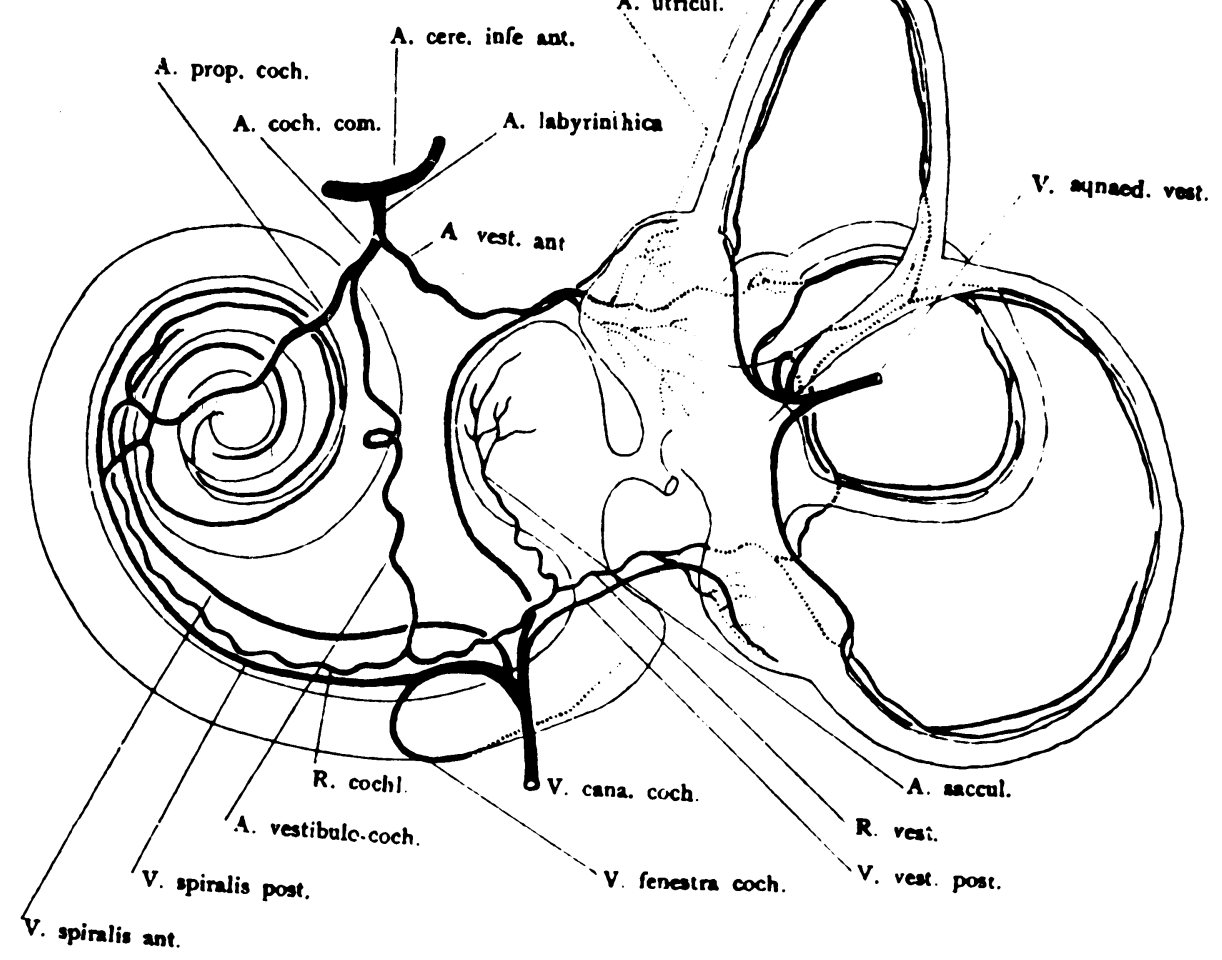

図 3 内耳の血管支配 (D. Nabeya ${ }^{11}$ ) から引用) 


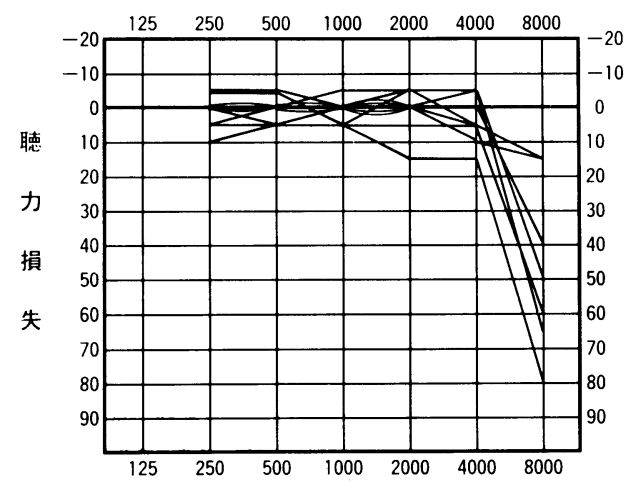

図 4 初搒時急隊型突発性難聴のうち治癒 9 例の 固定時オージオグラム

5 周波数の聴力損失值の平均の等をみると, 治 癒例は $24 \mathrm{~dB}$, 著明回復例は $50 \mathrm{~dB}$, 回復例は 19 $\mathrm{dB}$ ，不変例は $4 \mathrm{~dB}$ であり，治癒例より著明回 復例のうが，㮩力改善度が大きいという矛盾が みられた，第二は，固定時恥力を 5 凮波数平均 でみると, 治療例は $2 \mathrm{~dB}$, 著明回復例は $23 \mathrm{~dB}$, 回復例は $17 \mathrm{~dB}$, 不変例は $13 \mathrm{~dB}$ であり, 著明回 復例の力が, 问復例, 不変例上り固定侍恥力が 琹かったとと，および，回復例，不変例の固定 時衈力は 5 夙波数壮均では, 判定基隻の治癒に 相当する $20 \mathrm{~dB}$ 以内に入っていたてとであった。 このような矛盾は, 初彰侍蛊力が様々なためと $4 \mathrm{KHz}$ の固定川察恥力指失值が影響しているた めに生じると思われた。

一方, 判定基準に含まれない $8 \mathrm{KHz}$ の聴力 についてみると, 初診将急䧙型の20例中の治癒 9 例で $8 \mathrm{KHz}$ の恥力が阼常となったものは, 僅かに 2 例しかなかった!（汹4）。また，初診 洔 $8 \mathrm{KHz}$ のしか低下していないために，初晾 時すでに判定基準の治癒に入る症例もみられ た。

以上から，高音急隊型咨発性難聴については
表 4 原因，誘因が考えられた急墜型突発難聴

$\begin{array}{ll}\text { 鼻をかんだ後 } & 3 \text { 例 } \\ \text { 潜水後 } & 3 \text { 例 } \\ \text { ストマイの既往 } & 2 \text { 例 } \\ \text { 騒音性 } & 1 \text { 例 } \\ \text { 梅毒血清反応陽性 } & 1 \text { 例 }\end{array}$

突発性難㮩の子後判定基準をそのまま適用する ことは無理であると思われた。

最後に，急墜型を呈する急性感音㩲聴の中 で，原内または誘内が刚らかなものについて検 行した（表4）。乙れは今までに述べた症例と は别のあのである.

鼻をかんだ後と潜水後が各 3 例であったが， いずれも父压変化に伴うもので，外リンパ瘦の 可能性が考えられた。

騒音性の 1 例は, 騒音丁事の最川に発症した もので $2 \mathrm{~K} \sim 8 \mathrm{KHz}$ が低下していた。 反対側聴 力は正常であった.

ストマイ注:射の既往例は, 注射当时の揌力検 査では異常のないととを確浔されていた浆:例で あるが，作余を䋂て，哭然難恥になったもの で，低音部は改畨したものの $2 \mathrm{KHz}$ 以上で難 恥が残った。アミノグリコシドの内耳障占を考 えると，単純に资発性摹媤之は考え難い症例で ある。

梅毒IIII清反応陽性例は40歳男性である。フラ フラ感と $4 \mathrm{KHz}$ 以上の難聴がみられたが, 内 リンパ水腫を示唆する所見はえられなかった。

以上から，高音急墜型资発性難聴の㗄合，間 診で父压:変化，騒音，楽物の既往を確認するこ と, 梅毒検査, 瘦孔症状検査を施行すること, 外リンパ㿉の疑いの強いものに対しては, 試験 的跂室開放術を施行することが必要と思われ た。

\section{論}

突発性難聵のうち，高商急墜型を示すものには，次の type のものがあることが分かった.

1. 早期に治癒する type の咨発性難聡で, 高音のみが改善しないもの. 
2. 蝸牛基底回転に限局した资発性難聴.

3. 突発性内耳障害という観点からみて，障害部位が前庭，半規管のへ片よっているもの.

4. 前庭蝸牛動脈の循環障害が考えられるもの.

5. 数日かけて悪化していく type の突発性難聴.

6. 外リンバ瘦が疑われる突発性難恥.

したがって, 高音急墜型突発性難聴については, 臨床上特に以下の注意が必要と思われた。

1. 問診上, 気圧変化, 楽物, 騒音などの既往はないか.

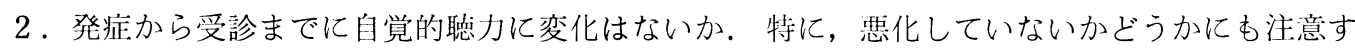
る.

3．域值上聴力検査を施行すること，補充現象の有無に注意し，後迷路障害を示唆するむのがな いか.

4 . 頭位眼振, 頭位変換眼振をみて, 耳石器の障害の有無をみる。また, 温度眼振検查を施行 し, 前庭, 半規管の障害の有無, 範囲を調べる.

5. 前庭蝸牛動脈領域に限定された障害例については, 特に血栓溶解剂を使用する.

6. 外リンパ瘦については, 試験的鼓室開放術を施行する.

本論文の一部は第27回日本オージオロジ一学会において口演発表した.

本研究は厚生省特定疾患, 急性高度難聴調査研究班の援助によるものである.

1) 設楽哲也, 岡本牧人：原因不明の高音急墜型急性 高度難聴, 厚生省特定疾患, 急性高度難聴調査研 究班. 昭和 58 年度研究業績報告書, $170 \sim 174$, 1984.

2 ) 厚生省特定疾患 : 突発性難聴調查研究班. 昭和 48 年度研究業績報告書, 1974.

3 ) 柳田則之, 他: Slow type の Sudden Deafness 亿関する検討. Audiology Japan 20:371 $372,1977$.

4 ) 寺山吉彦, 他：急速進行性感音難聴（急速性難 聴) の検討, 厚生省特定疾患, 特発性の感音難聴 調查研究班. 昭和56年度研究業績報告書, 21 25, 1982.

5 ) 平出文久, 他：急速進行性感音難聴 2 症例の検 討, 厚生省特定疾患, 急性高度難聴調査研究班. 昭和57年度研究業績報告書, $23 \sim 28,1983$.

6 ) 村上 泰: 突発性難聴の疫学, 病因, 治療に関す 万研究. 厚生省特定疾患, 突発性難聴調査砳究 班. 昭和50年度研究業績報告書, 1976 .

7 ) 三宅 弘：乫発性難聴の臨床. 日耳鼻第76回総会
宿題報告モノグラフ, 1975.

8 ）田代直樹, 他：良性発作性頭位メマイ様の眼振を 呈した突発性難聴. 日耳鼻 $85 ： 1325 \sim 1326$, 1982.

9) Barany R: Diagnose von Krankheitserscheinungen im Bereich des Otolithenapparatus. Acta Otolaryngol $2: 434 \sim 437$, 1921.

10）久保 武, 他：突発性難聴患者に対する Defibrase (Batroxobin) 投与の効果について. 日耳 鼻 $86: 1294,1983$.

11) Nabeya D: A Study in the Comparative Anatomy of the Bloodvascular System of the Internal Ear. Acta Scol Med Univ Imp Kioto $6: 1 \sim 132,1923$.

原稿到着：昭和59年 9 月 12 日

別刷請求先：岡本牧人

厂228 神奈川県相模原市北里 1 丁目15番 1 号 北里大学医学部耳鼻咽喉科学教室 